\title{
Correction to: EIF4A3-induced circular RNA MMP9 (circMMP9) acts as a sponge of miR- 124 and promotes glioblastoma multiforme cell tumorigenesis
}

Renjie Wang ${ }^{1,2}$, Sai Zhang ${ }^{1,2}$, Xuyi Chen ${ }^{1,2}$, Nan Li ${ }^{1,2}$, Jianwei Li ${ }^{1,2}$, Ruichao Jia ${ }^{1,2}$, Yuanqing Pan ${ }^{3}$ and Haiqian Liang ${ }^{1,2,4^{*}}$

Correction to: Mol Cancer 17, 166 (2018)

https://doi.org/10.1186/s12943-018-0911-0

Following the publication of the original article [1], authors found out that it contains a duplication error within Figs. 4h and 5b. The correct version of Figs. 4 and 5 are shown below. In addition, the correct version of Fig. 1 and Additional file 1 are also provided in this paper.

\section{Supplementary information}

Supplementary information accompanies this paper at https://doi.org/10. 1186/s12943-020-01271-w.

Additional file 1 : Table S1. The primers used in this study
Published online: 30 October 2020

\section{Reference}

1. Wang $R$, Zhang $S$, Chen $X$, et al. ElF4A3-induced circular RNA MMP9 (circMMP9) acts as a sponge of miR-124 and promotes glioblastoma multiforme cell tumorigenesis. Mol Cancer. 2018;17:166. https://doi.org/10. 1186/s12943-018-0911-0.

\begin{abstract}
Author details
'Institute of Traumatic Brain Injury and Neurology, Characteristic Medical Center of Chinese People's Armed Police Force, Tianjin 300162, China. ${ }^{2}$ Department of Neurosurgery, Characteristic Medical Center of Chinese People's Armed Police Force, Tianjin 300162, China. ${ }^{3}$ Department of Basic Medicine, Tianjin Medical College, Tianjin 300222, China. ${ }^{4}$ Chinese Glioma Cooperative Group (CGCG), Tianjin, China.
\end{abstract}

The original article can be found online at https://doi.org/10.1186/s12943018-0911-0.

* Correspondence: lianghaiqian711@163.com

${ }^{1}$ Institute of Traumatic Brain Injury and Neurology, Characteristic Medical Center of Chinese People's Armed Police Force, Tianjin 300162, China

${ }^{2}$ Department of Neurosurgery, Characteristic Medical Center of Chinese People's Armed Police Force, Tianjin 300162, China

Full list of author information is available at the end of the article

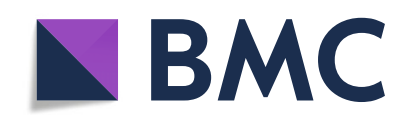

(- The Author(s). 2020 Open Access This article is licensed under a Creative Commons Attribution 4.0 International License, which permits use, sharing, adaptation, distribution and reproduction in any medium or format, as long as you give appropriate credit to the original author(s) and the source, provide a link to the Creative Commons licence, and indicate if changes were made. The images or other third party material in this article are included in the article's Creative Commons licence, unless indicated otherwise in a credit line to the material. If material is not included in the article's Creative Commons licence and your intended use is not permitted by statutory regulation or exceeds the permitted use, you will need to obtain permission directly from the copyright holder. To view a copy of this licence, visit http://creativecommons.org/licenses/by/4.0/. The Creative Commons Public Domain Dedication waiver (http://creativecommons.org/publicdomain/zero/1.0/) applies to the data made available in this article, unless otherwise stated in a credit line to the data. 


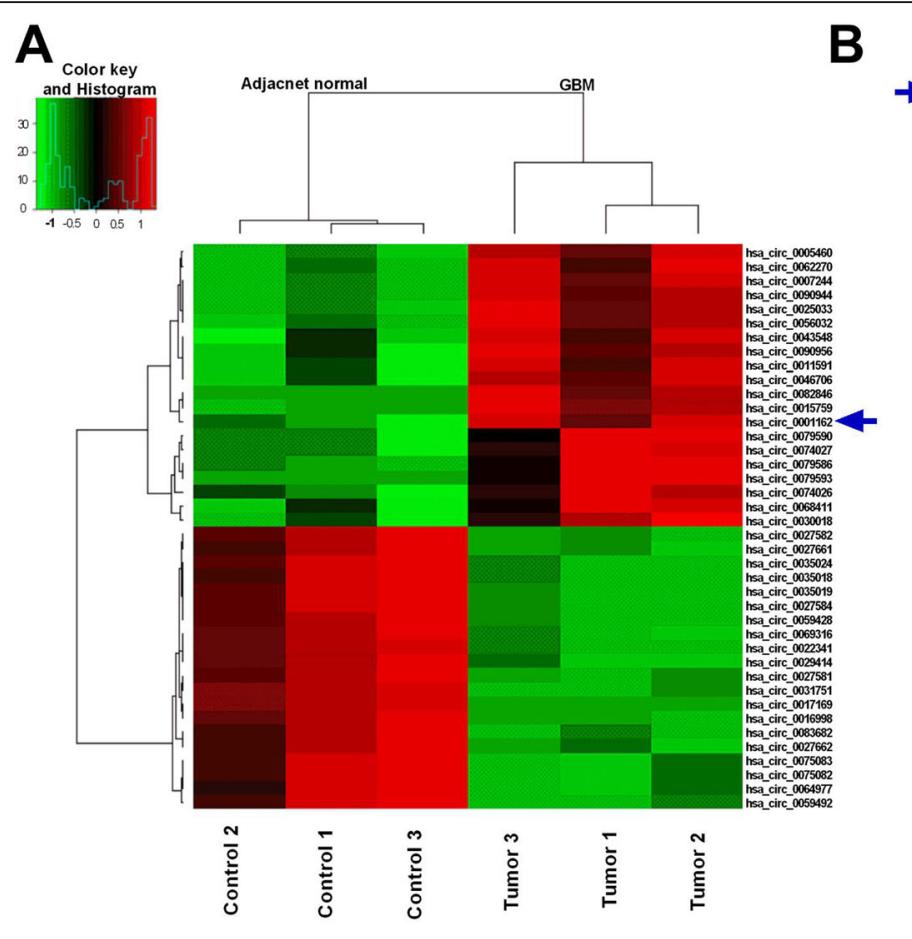

\begin{tabular}{|c|c|c|c|}
\hline circRNA ID & Gene symbol & $\mathrm{P}$-values & Foldchange \\
\hline c_0001162 & MMP9 & 0.008783486 & 68. 56811775 \\
\hline hsa_circ_0074027 & PITX1 & 0.019770255 & 31.85543861 \\
\hline hsa_circ_0074026 & PITX1 & 0.035068376 & 27. 59015387 \\
\hline hsa_circ_0030018 & POSTN & 0.039059375 & 25. 12780009 \\
\hline hsa_circ_0062270 & $\mathrm{CDC} 45$ & 0.013703665 & 24. 53759834 \\
\hline hsa_circ_0079593 & IGF2BP3 & 0.046465377 & 22.41348807 \\
\hline hsa circ 0079586 & IGF2BP3 & 0.035775342 & 21. 03777909 \\
\hline hsa_circ 0079590 & IGF2BP3 & 0.02746246 & 19. 84235718 \\
\hline hsa_circ_0025033 & FOXMI & 0.010468219 & 19. 84042455 \\
\hline hsa_circ_0068411 & IGF2BP2 & 0.024015021 & 19.0230006 \\
\hline hsa_circ_0056032 & BUB1 & 0.004696652 & 18. 80333996 \\
\hline hsa_circ_0090956 & KIF4A & 0.01568687 & 18. 39877432 \\
\hline hsa_circ_0005460 & MELK & 0.00195994 & 18. 27432414 \\
\hline hsa_circ_0046706 & NDC80 & 0.014560413 & 17. 97206882 \\
\hline hsa_circ_0090944 & KIF4A & 0.005940869 & 17. 70629049 \\
\hline hsa circ 0015759 & ASPM & 0.013601707 & 17. 63230893 \\
\hline hsa_circ_0082846 & EZH2 & 0.015286804 & 16. 98151835 \\
\hline hsa_circ_0011591 & CLSPN & 0.013999997 & 16. 94207344 \\
\hline hsa_circ_0043548 & TOP2A & 0.015990149 & 16. 8752647 \\
\hline hsa_circ_0007244 & NCAPG & 0.003155053 & 16. 84981189 \\
\hline hsa_circ_0075082 & CPLX2 & 0.010193366 & 0.049725715 \\
\hline hsa_circ_0035018 & СКMT1B & 0.019548537 & 0. 049429619 \\
\hline hsa_circ_0016998 & SLC35F3 & 0.009317754 & 0.049176407 \\
\hline hsa_circ_0059492 & PCSK2 & 0.02282259 & 0.048776872 \\
\hline hsa_circ_0059428 & SNAP25 & 0.014750828 & 0.046274837 \\
\hline hsa_circ_0029414 & TMEM132D & 0.005164038 & 0.045545135 \\
\hline hsa_circ_0022341 & SYT7 & 0.004227349 & 0.045480631 \\
\hline hsa_circ_0027661 & SYTI & 0.015086421 & 0.044997453 \\
\hline hsa_circ_0027584 & TRHDE & 0.012346874 & 0.044431917 \\
\hline hsa_circ_0027662 & SYTI & 0.01205194 & 0.043078715 \\
\hline hsa_circ_0075083 & CPLX2 & 0.009543625 & 0. 042909266 \\
\hline hsa_circ_0069316 & KCNIP4 & 0.00797961 & 0.040449038 \\
\hline hsa_circ_0027582 & TRHDE & 0.015517342 & 0. 038957523 \\
\hline hsa_circ_0064977 & $\mathrm{CCK}$ & 0.020494221 & 0.03724557 \\
\hline hsa_circ_0035024 & CKMT1A & 0.01649461 & 0.036083489 \\
\hline hsa_circ_0035019 & СКМТ 1B & 0.021312292 & 0.035849726 \\
\hline hsa_circ_0031751 & LRFN5 & 0.002868536 & 0.034340334 \\
\hline hsa_circ_0027581 & TRHDE & 0.017678499 & 0.033828065 \\
\hline hsa_circ_0017169 & RYR2 & 0.011066709 & 0.02655339 \\
\hline hsa_circ_0083682 & NEFM & 0.020136892 & 0.01626412 \\
\hline
\end{tabular}

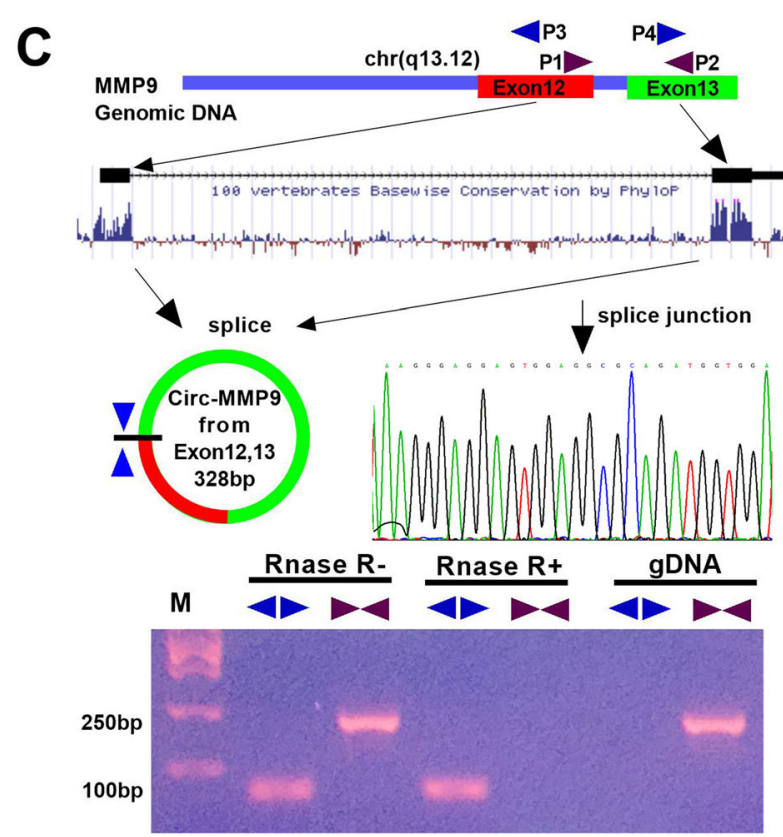

D E
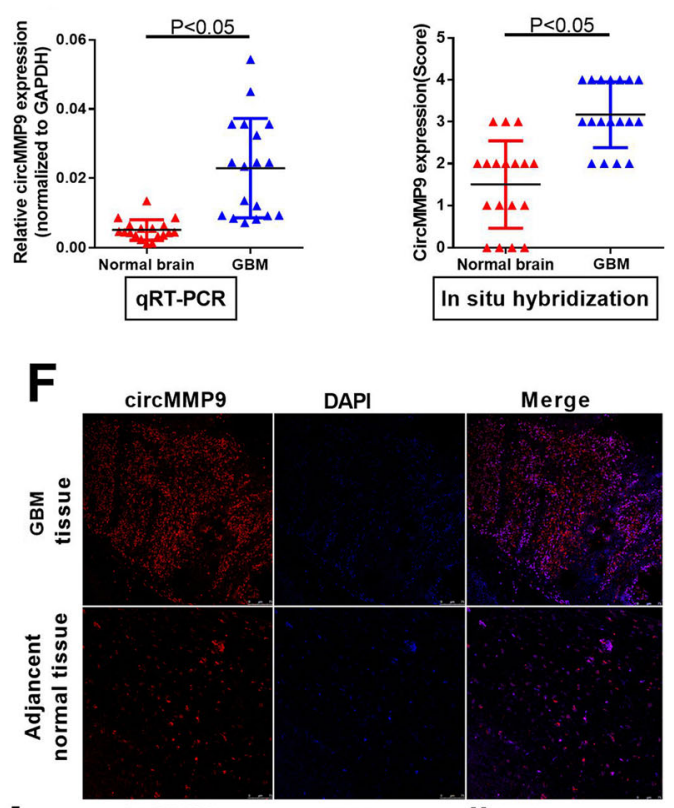

G
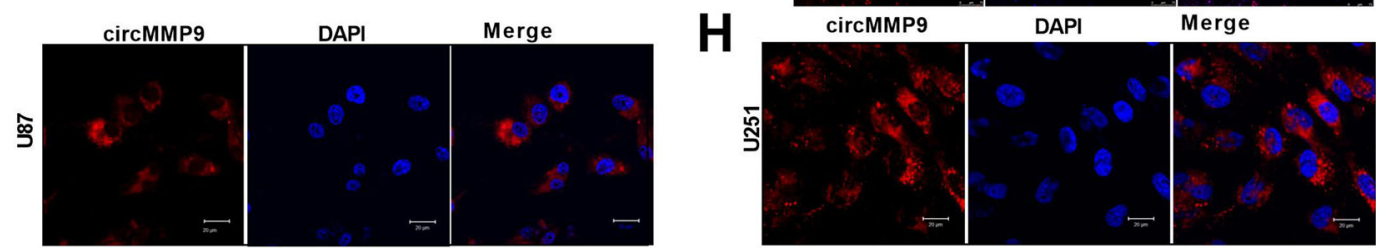

Fig. 1. (See legend on next page.) 
(See figure on previous page.)

Fig. 1. Characterization of circMMP9 in human GBM. a Clustered heat map showing tissue-specific circRNAs (top 20 upregulated and downregulated circRNAs), which are displayed on a scale from green (low) to red (high), between three human GBM tissues and adjacent normal tissues. The arrow represents the circRNA (hsa_circ_001162) with the greatest differential expression. $\mathbf{b}$ Detailed information for the top 20 upregulated and downregulated circRNAs according to the extent. c Schematic representation of circMMP9 formation. The splice junction sequence was Sanger sequenced, and the RNAs were detected via PCR. Divergent primers could produce circRNAs in cDNA but not in genomic DNA (gDNA); convergent primers could produce CDNA and gDNA. $\mathbf{d}$ The expression level of circMMP9 was detected by qRT-PCR in GBM tissues and adjacent normal brain tissues ( $n=18, P<0.05)$; GAPDH served as the internal control. e-f circMMP9 expression was measured using in situ hybridization (FISH) in GBM tissues and adjacent normal brain tissues $(n=18, P<0.05)$. $\mathbf{g}$-h Confocal FISH was performed to determine the location of circMMP9 in U87 and U251 cells 


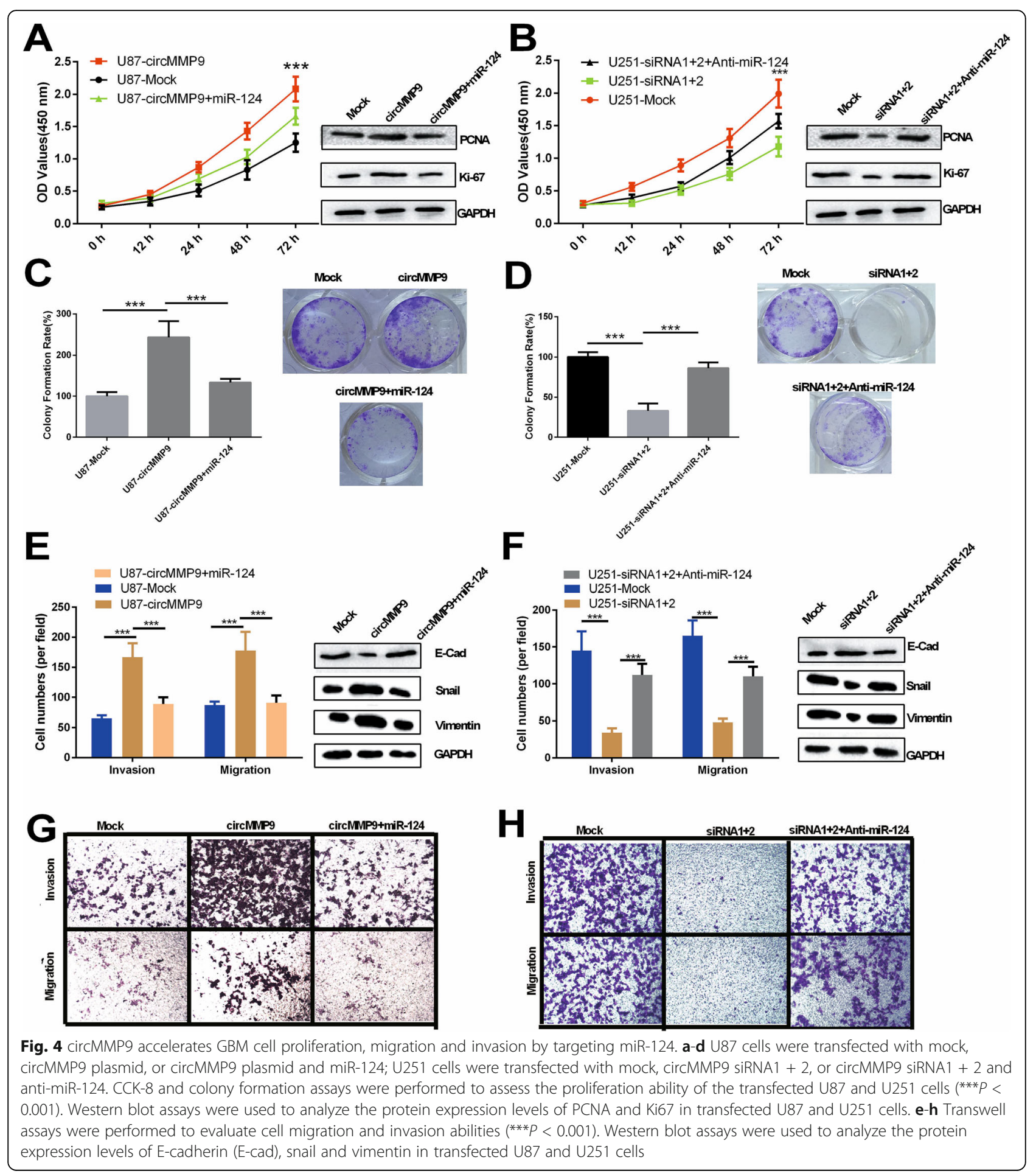




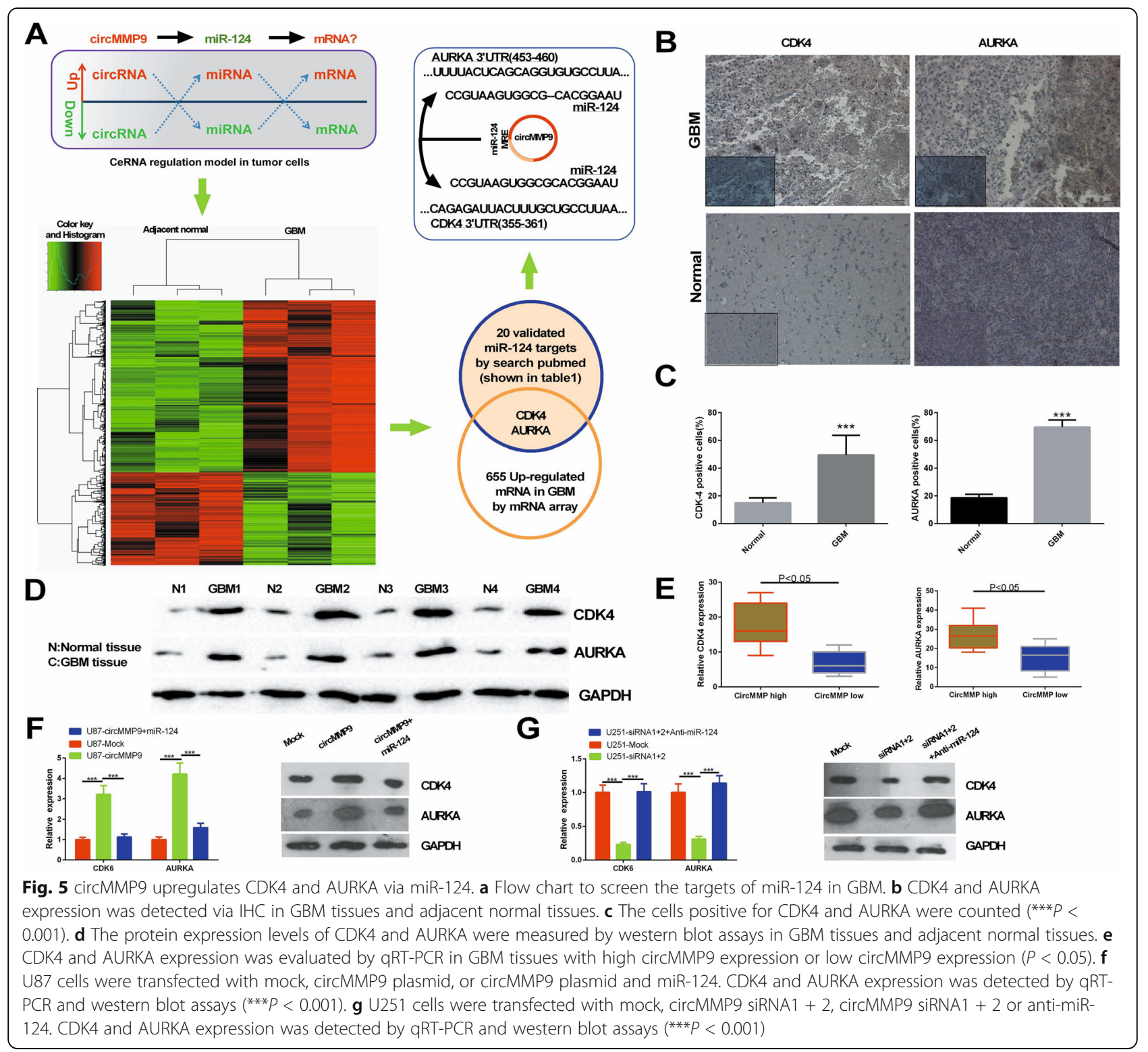

